\title{
Public sector entrepreneurship: introduction to the special section
}

\author{
Albert N. Link ${ }^{1}$ ii
}

(C) Associazione Amici di Economia e Politica Industriale 2016

Public sector entrepreneurship has been defined by Leyden and Link (2015) as the promulgation of innovative public policy initiatives that generate greater economic prosperity by transforming a status-quo economic environment into one that is more conducive to economic units engaging in creative activities in the face of uncertainty. In today's economy, public sector entrepreneurship affects that transformation primarily by increasing the effectiveness of knowledge networks; that is, by increasing the heterogeneity of experiential ties among economic units and the ability of those same economic units to exploit such diversity. Through policy initiatives that are characterized by public sector entrepreneurship, there will be more development of new technology and hence more innovation throughout the economy.

This special section of Economia e Politica Industriale-Journal of Industrial and Business Economics contains four papers authored by eminent scholars who address different dimensions of public sector entrepreneurship. The first paper, "Creativity for Invention Insights: Corporate Strategies and Opportunities for Public Entrepreneurship", by John Scott offers evidence about invention insights and about corporate strategies to promote those insights within the context of a model of the invention-insight discovery process. Scott uses his evidence for two purposes. One purpose is to identify a novel new opportunity-initiation of policies to stimulate invention insights that directly combine unusually large numbers of knowledge elements-for public sector entrepreneurship to speed the pace of technological progress and the opening up of altogether new areas of science and technology, and another purpose is to delimit the appropriate form of policy-promotion of competition and the free exchange of ideas-to exploit the opportunity.

Albert N. Link

anlink@uncg.edu

1 Department of Economics, University of North Carolina at Greensboro, Greensboro, NC, USA 
The second paper, "Universities as Partners in Research Joint Ventures", by Dennis Leyden represents a clever application of economic theory to construct a model to explain when a firm will invite a university to participate in a research joint venture. Not only is this model relevant for understanding how a firm might respond to the U.S. National Cooperative Research Act of 1984-a quintessential example of government as entrepreneur-but also it provides a needed foundation for future empirical work related to RJVs.

The third paper in this special section is by David Audretsch, Erik Lehmann, and Matthias Menter. In "Public Cluster Policy and New Venture Creation" the authors address public cluster policy and the associated impact on entrepreneurial engagement with reference to its impact on new venture creation in Germany. Their empirical results confirm that public cluster policies positively affect regional entrepreneurial activities, but only in part. The overall effect of governmental subsidization-a public sector entrepreneurial treatment effect-is rather low compared to the impact of local research intensive universities and the innovative milieu on new venture creation.

The final paper in the special section is by James Cunningham, Paul O'Reilly, Brendan Dolan, Conor O'Kane, and Vincent Mangematin, and it is titled "Publicly Funded Principal Investigators' Allocation of Time for Public Sector Entrepreneurship Activities." Using a sample of Irish researchers, the authors explore publicly funded principal investigators' (PIs) allocation of time for public sector entrepreneurship activities. Among their many findings, they report that PIs who spend more time on general research related activities allocated a higher proportion of time to technology transfer activities, and that PIs who spend more time on technology activities engaged more in end-of-project reports and collaborative research with industry. With respect to boundary spanning activities, the authors find that PIs who spend more time on research were engaged more in direct consultation with industry end-users and direct consultation with their technology transfer office at the pre-proposal stage of their selected project and they had a significantly larger than average amount of industry partners.

\section{Reference}

Leyden, D. P., \& Link, A. N. (2015). Public sector entrepreneurship: U.S. technology and innovation policy. New York: Oxford University Press. 